\title{
Recurrent decidual cast with membranous dysmenorrhea
}

\author{
Jyoti $^{1}$, Suman Kumari ${ }^{1 *}$, Devender Kumar², \\ Pratiksha Gupta $^{1}$, Nupur Gupta ${ }^{1}$, Anand Kumar ${ }^{3}$
}

\begin{abstract}
${ }^{1}$ Department of Obstetrics and Gynecology, ESI-PGIMSR, Basaidarapur, New Delhi, India
${ }^{2}$ Department of Anaesthesia and Critical care, Max Superspeciality Hospital, Shalimar Bagh, New Delhi, India

${ }^{3}$ Department of Pathology, ESI-PGIMSR, Basaidarapur, New Delhi, India
\end{abstract}

Received: 08 July 2018

Revised: 02 January 2019

Accepted: 11 January 2019

\author{
*Correspondence: \\ Dr. Suman Kumari, \\ E-mail: sumanmishi@gmail.com
}

Copyright: (C) the author(s), publisher and licensee Medip Academy. This is an open-access article distributed under the terms of the Creative Commons Attribution Non-Commercial License, which permits unrestricted non-commercial use, distribution, and reproduction in any medium, provided the original work is properly cited.

\begin{abstract}
Decidual cast is the entire sloughed endometrium that takes the form of the endometrial cavity. It causes membranous dysmenorrhea because the intact cast passes through an undiluted cervix. It may be associated with ectopic pregnancy, incomplete abortion, non-pregnant state with use of progesterone, Depot medroxyprogesterone acetate (DMPA), rarely with oral contraceptive pills. Authors are reporting a case of recurrent decidual caste formation with membranous dysmenorrhoea in 33 years old women $\mathrm{P}_{3} \mathrm{~L}_{3}$ who was on norethisterone acetate treatment for a typical uterine bleed (AUB). She presented with heavy menstrual bleeding with severe dysmenorrhea in Gynae causality of ESI Basaidarapur medical college, Delhi. She expelled decidual caste and required therapeutic Dilation and Curettage (D and C) to control bleeding per vaginum. Her histopathology report showed marked decidua like change of the stroma but no villi suggestive of endometrial caste.
\end{abstract}

Keywords: Atypical uterine bleeding, Decidual cast, Membranous dysmenorrhea

\section{INTRODUCTION}

A decidua is endometrium that is hormonally prepared for pregnancy.

Dysmenorrhea membranate is a clinicopathological term first described by G.B. Morgagni in $18^{\text {th }}$ century. Clinically, there is shedding of the endometrium in a shape resembling the uterus ${ }^{1}$. It can cause intense cramping pain because the intact cast passes through an undiluted cervix.

It may be associated with ectopic pregnancy, incomplete abortion, non-pregnant state with use of progesterone, DMPA, rarely with oral contraceptive pills. The theory of hyper-progesteronism has been hypothesized and cases have been observed of decidual cast expulsion following progesterone. ${ }^{2}$ Histopathologically, decidualization of endometrial stroma and atrophy of endometrial glands is seen.

\section{CASE REPORT}

A 33 years old lady, $\mathrm{P}_{3} \mathrm{~L}_{3}$ presented in our gynae causality with chief complain of heavy menstrual flow and severe dysmenorrhea. She was having heavy menstrual bleeding (HMB) since 1 year with passage of clots.

Her previous menstrual cycles were regular. She was taking tablet Norethisterone acetate 5mg TDS for 4 months. She was hypothyroid, on tablet eltroxin 100ug since 5 years. On examination, her general condition was stable. Systemic examination was found to be normal. Her investigation revealed moderate anaemia with 
hemoglobin of $7 \mathrm{gm} / \mathrm{dL}$. Her platelet count and coagulation profile revealed no abnormality. LFT and KFT was within normal range. Urine pregnancy test (UPT) was negative Analgesic was given for severe dysmenorrhea but not relieved. On prevaginal examination, uterus was anteverted 10 weeks size and bilateral adenexa was normal.

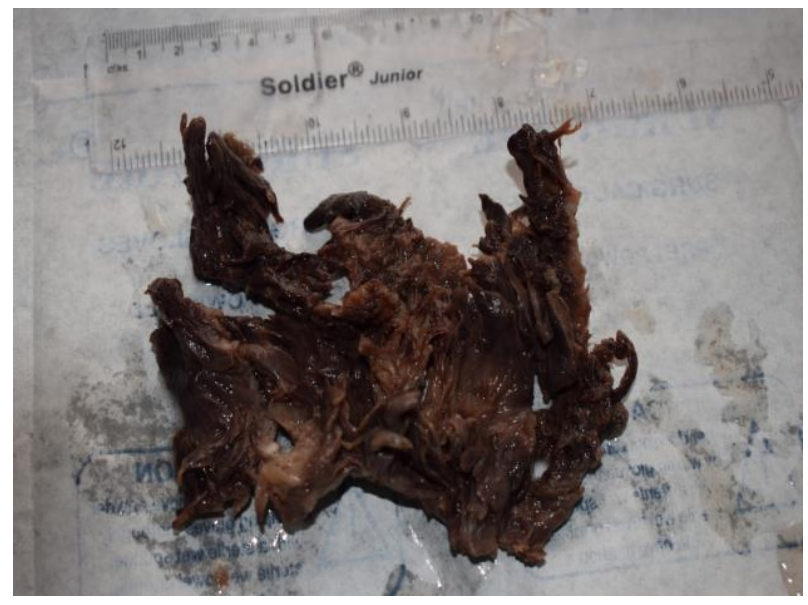

Figure 1: Formaline preserved decidual cast.

After four hours of admission, she expelled uterine shaped soft mass of $7 \times 4 \times 3$ which looked like retained product of conception. Pain relieved after expulsion, but bleeding continued heavily.

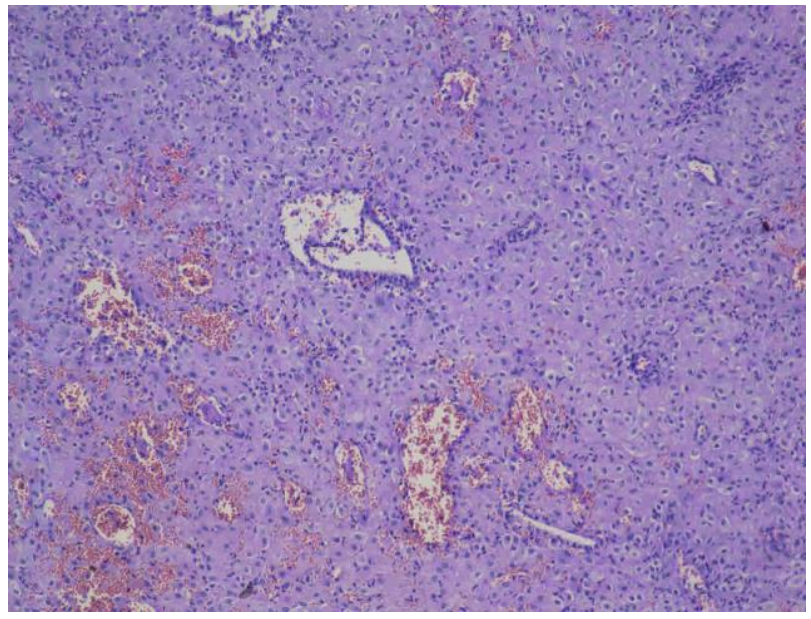

Figure 2: Microscopy: partially necrotic endometrium showing marked decidua like change of the stroma without villi.

After arranging blood, patient was shifted to minor OT for therapeutic D and C. Her endometrial sample was sent for histopathology examination and report revealed marked decidua like change of the stroma, but no villi seen suggestive of endometrial caste. Her beta hCG report was $0.01 \mathrm{ug}$. Patient was discharged after anaemia correction. After 2 months, she was again admitted with similar complains of membranous dysmenorrhea and heavy menstrual flow. Similar decidual caste was again expelled and histopathology report was same, decidual like changes of stroma. Treatment was changed to continuous oral contraceptive pills and patient got relieved.

\section{DISCUSSION}

Decidual caste is an entity that has been reported periodically in the last few decades through case reports and studies. Unfortunately, the etiology remains unknown. There are many theories regarding the pathophysiology of decidual casts. ${ }^{3,4}$ Asch and Greenblatt proposed that an increase in estrogen and progesterone production with incomplete disintegration of the endometrium results in a thickened endometrium that ultimately contracts to expel its contents. ${ }^{5}$ Greenblatt et al, have postulated an infections process. ${ }^{6}$ Others have suggested the etiology is based in prostaglandin production. $^{4,7}$ Rabinerson et al, suggested that integrins which mediate cell-cell adhesion events may play an important role in the development of membranous dysmenorrhea. $^{7}$

This condition is seen mainly in young women between 20 and 40 years and all of them were using or just stopped using a hormonal contraceptive; However, decidual cast does not seem to be limited to a hormonal formulation or a route of administration. ${ }^{8}$ In the case we reported, the patient was taking Norethindrone acetate. Other formulations leading to endometrial caste formations are injectable Depo medroxyprogesterone acetate (DMPA), drospirenone, ciproterone, norgestimate, desogestrel, norethindrone acetate, transdermal patch. ${ }^{2,7,9-12}$ The differential diagnosis of mass per vaginum with cramping pain abdomen and bleeding pervaginum are aborted pregnancy, rhabdomyosarcoma, polyp, and finally decidual cast. Usually, the diagnosis of this condition is established on histopathological examination of expulsed tissue or after endometrial curettage. ${ }^{13}$

Present study showed, on routine hematoxylin and eosin stained sections, decidualized endometrium with regressive changes or focal hemorrhagic necrosis and infiltrated by neutrophils without any villi. ${ }^{3,8,9}$ Study also showed endometrial caste has a good prognosis, does not seem to be associated with negative consequences in long term but risk recurrence is there with continue use of same progesterone. Every woman should obtain detailed information about the possible side effects of hormonal therapies including endometrial cast formation.

\section{CONCLUSION}

We conclude that in nonpregnant women on hormonal therapy (progesterone or oral contraceptives) complaining of severe cramping abdominal pain and bleeding with passage of tissue, decidual caste with dysmenorrhea membranacea though rare, should be thought as a diagnosis. 
Funding: No funding sources

Conflict of interest: None declared

Ethical approval: Not required

\section{REFERENCES}

1. Malik MF, Adekola H, Porter W, Poulik JM. Passage of decidual cast following poor compliance with oral contraceptive pill. Fetal Pediatr Pathol. 2015; 34(2):103-7.

2. Omar HA, Smith SJ. Membranous dysmenorrhea: a case series. Scient World J. 2007;7:1900-3.

3. Sen Y, Cimbek EA, Ugras NS. Decidual cast after discontinuation of oral contraceptives use in a young girl. J Pediat Adolesc Gynecol.2013;26(6):e127-9.

4. Appelbaum H. Membranous dysmenorrhea: a complication of treatment for endometriosis. Obstet Gynecol. 2010;116(2):488-90.

5. Asch RH, Greenblatt RB. Primary and membranous dysmenorrhea. South Med J. 1978;71(10):1247-9.

6. Greenblatt RB, Hammond DO, Clark SL. Membranous dysmenorrhea: Studies in etiology and treatment. Obstet Gynecol Survey. 1956;11(6):832-5.

7. Rabinerson D, Kaplan B, Fisch B, Braslavski D, Neri A. Membranous dysmenorrhea: the forgotten entity. Obstet Gynecol. 1995;85(5):891-2.

8. Maciel R, Rodrigues S, Inocêncio G, Saraiva J, Montalvão M. Membranous dysmenorrhea: a rare and unknown entity. Acta Obstet Ginecol Port. 2014;8(4):402-4.

9. Singh V, Talib N, Strickland J. Decidual cast in a girl receiving depot medroxyprogesterone acetate-a case report. J Pediat Adolescent Gynecol. 2007;20(3):191-4.

10. Oliveira PP, Eyng C, Zin RM, Menegassi J. Membranous dysmenorrhea: a forgotten disease. Brazil J Gynecol Obstet. 2009;31(6):305-10.

11. Rouanet JP, Daclin PY, Turpin F, Karam R, Prayssac-Salanon A, Courtieu CR, Maubon AJ. Imaging of membranous dysmenorrhea. Europ Radiol. 2001;11(6):952-4.

12. Torres A, Baszak-Radomańska E, Torres K, Paszkowski T, Staśkiewicz GJ, Wozniakowska E. A case of unusual course of adolescent menorrhagia: decidual cast as a side effect of treatment. Fertil Steril. 2009;92(5):1748-e5.

13. Veldman J, Van Houdenhove B, Verguts J. Chronic fatigue syndrome: a hormonal origin? A rare case of dysmenorrhea membranacea. Arch Gynecol Obstet. 2009;279(5):717-20.

Cite this article as: Jyoti, Kumari S, Kumar D, Gupta P, Gupta N, Kumar A. Recurrent decidual cast with membranous dysmenorrhea. Int J Reprod Contracept Obstet Gynecol 2019;8:738-40. 